\title{
The Role of Alternative Dispute Resolution in Trans- Boundary Land Dispute: The Case of Ikot Idaha and Osuk Ediene Communities in Akwa Ibom State, Nigeria
}

\author{
Ukpong-Umo, R.E. ${ }^{1}$ \\ Udobia, I.U. ${ }^{1}$ \\ Agwu, A.O. ${ }^{2}$
}

Department of Sociology ${ }^{1}$

Ritman University, Ikot Ekpene, Nigeria

Department of General Studies ${ }^{2}$

Abia State University, Uturu, Nigeria

\begin{abstract}
The perennial land dispute of Ibime Water Trench, a trans-boundary land area between Ikot Idaha and Osuk Ediene Communities in Ikono Local Government Area of Akwa Ibom State has led to discord, hatred and dissonance over several years in the past. Despite repeated efforts by both parties to identify and resolve the underlying issues and contain the problem, it was found to have recurred after a period of seeming calm. This paper therefore aims at investigating and identifying the underlying factors that trigger recurrent trans-border conflicts between Ikot Idaha and Osuk Ediene Communities and the application of Alternative Dispute Resolution (ADR), using the Mediation Technique in conflict resolution. Data were elicited through the indept interview method and analysed using the content analysis method. Result shows that through the Mediation process, both disputing parties were able to resolve their differences and have been living and sharing in the Ibime water resources together and peacefully for over thirty years. In line with the theory of Conflict Resolution, the development of Impact Sensitive Outcome Mapping as a form of monitoring and evaluation was adopted to serve as an intervention to proffer a lasting solution for a peaceful coexistence among the people of both communities.
\end{abstract}

\section{Introduction}

Conflict has been defined as the deliberate attempt to oppose, resist, or coerce the will of another or others (Green, 1960), and this is interpreted as the contest between people of diverse interests, needs, ideas, values, goals or beliefs (Ukpong- Umo, 2013). In contemporary times and in most parts of the world, conflict which is an apposed behaviour between two groups seeking for scarce resources or the pursuit of incompatible interest and goals by different groups is becoming not only common, but escalating. The West African sub-region and particularly Nigeria is not left out as it has been plagued by intra-state, inter-state, ethnic and religious conflicts and indeed, within the past few decades, ethnic and communal clashes have escalated in most parts of the country. These include the farmers- herdsmen clashes in some parts in the North which have spilled and diffused to other parts including the South-East; 
land disputes; water/nautical boundary disputes; community-investor disputes; indigene-settler disputes, etc., all leading to wanton destruction and loss of lives and property (Mwanasali, 2006; Egwu, 2006).

As averred in Ekong (2010) Conflict is that form of social interaction in which the actors seek to obtain scarce reward by eliminating or weakening other contenders through various forms including fist- fight, threats, legislation or total annihilation. Ekong (2010) also affirmed that conflict is almost inevitable as part of any interactive social process, but that the handling style is critical because any conflict situation that is not handled properly, may escalate, resulting in disastrous outcomes.

This calls for in-depth understanding of how to manage conflict when they arise, in order to avoid unpleasant and destructive escalations. Therefore, knowledge of how to handle particularly land related conflict is very important in achieving cohesion and peaceful coexistence among rural communities as this will foster and facilitate rural development (Best, 2006). This, on the other hand will also enhance urban and national progress.

The study aims to show the significance and critical role of ADR through the use of mediation technique in resolving particularly trans-boundary land disputes between communities. Discussion on this paper centres on the use of Alternative Dispute Resolution (ADR) approach in the management of conflict, with particular reference to the Mediation process.

This study is basis upon the theory of prescriptive Realism - a variant of Realism which highlights inherency and traces the root of conflict to a flaw in human nature. Here, mankind is seen to be selfish and engaging in the pursuit of personalised self- interest (Faleti, 2006). Realism, which originates from classical Political theory, share theological and biological doctrines about the apparent weakness and individualism inherent in human nature and thus sees the individual level as the starting point for the explanation of conflict (Faleti, 2006). Accordingly, the Prescriptive Realist supports that conflict decisions, whether by individuals, groups or States are taken based on moral justification to defend their basic interests and ensure self-preservation as parties engage in the pursuit of scarce and competitive interest. This study is significant for both communities as it can conduce to forestall the psycho-social discordances, cultural discontinuities and economic losses that trail the dramatic scenario of each conflict episode for both communities.

In the case of Ikot Idaha and Osuk Ediene communities, the disputed land lies at South Western boundary of Osuk Ediene facing the high forest. Several attempts have been made by both communities in the past and their allies to broker peace but with no significant progress. However, the recurrent crisis due to relapse of conflict after settlement and several years of seeming peaceful coexistence is worrisome. The main objective of this study therefore is to find out the underlying factors that trigger recurrent trans- border conflicts between Ikot Idaha and Osuk Ediene Communities in Ikono Local Government Area, Akwa Ibom State. The study also intends to find out ways to resolve the issues 
leading to the persistence of conflict in the area and create a germane environment conducive for peaceful co-existence.

It is often deduced that no meaningful development can take place in an environment of chaos, where crises and conflicts preponderate. Since conflicts of all forms abound in human interactive processes, and particularly, land related conflicts in an agrarian society such as Nigeria, this study on strategic conflict resolution is significant.

\section{Mediation as an ADR Process}

According to Nader (1984), Mediation is one of the types of Alternative Dispute Resolution (ADR), and ADR is a composite concept which refers to any means of settling disputes outside the court room. Nader (1984) also posits that ADR uses early neutral evaluation, negotiation, conciliation and arbitration processes as composite designs to achieve results, and further stipulates that it includes dispute resolution processes and techniques that act as a means for disagreeing parties to come to an agreement, short of litigation. It is therefore a collective term for the ways that parties in a conflict can settle differences with the help of a third party.

Specifically, Hoffmann (1992) sees Mediation as that intervention by a third party in a negotiation or conflict, where an acceptable third party, who has limited or no authoritative decision- making power but who assists the involved parties in voluntarily reaching a mutually acceptable settling of issues in dispute. For the purpose of this study however, Mediation shall be taken to mean that tool or aspect of alternative dispute resolution approach involving an informal, impartial, neutral, voluntary, and confidential third party, who facilitate understanding, communication and negotiation between disputants, in a deliberate effort to assist them in reaching a mutually acceptable resolution to their dispute.

The whole idea about ADR revolves around the search for and application of non-conventional approaches of settling disputes and resolving conflict situations, using the least expensive methods and in ways that satisfy the parties as well as ways that preserve relationships after settlement might have been reached. ADR is specifically meant to serve as an alternative to the official conventional means of settling disputes through courts and by litigation processes (Godongs, 2006). As averred in Best (2006), the management of conflict using peaceful, non- violent methods has, for a long time been around in African societies, and there is much more now, even as it was long ago, the preference for the peaceful settlement of dispute along the lines prescribed by the institutions and values of the community. This is the thrust of ADR. 


\section{History of the Disputed Land and Issue of Contention}

The exact portion of land in dispute lies horizontally on the South East border of Osuk Ediene at approximately latitude $5^{\circ} 10^{1} \mathrm{~N}$ and $5^{\circ} 48^{1} \mathrm{E}$.

The land in question measures approximately 3 hectares square, and encroaches into the Ibime (Ibiomo) water resource - a large Oasis and natural trench that habours species of water and land animals as well as sea birds valuable for their game (Umor, 1999). Ibime resort is prestigious and popular both for Ikot Idaha and Osuk Ediene, and around the adjoining communities because of its multiple values which include tourism potentials, food and medicinal benefits, water resources for drink, washing, laundry, farming, art and aesthetic sceneries. Many of the animals and birds found around this wonderful water trough have been attracted to this large water pond to take respite, drink and bathe especially during the high temperatures of the dry season, when all other water sources are dried- up and everywhere is dry and hot.

Apparently, in the heart of the dry season in Nigeria and perhaps other warm regions around the world, living organisms with locomotive abilities tends to mobilize towards areas that are cool, serene, airy and lushy, and have the presence of water for drink, bathe and washing, and Ibime provides all of these, and the water trough retains water content and its attendant resources sometimes until late February of the followed year, and therefore serves as a local resort. This local resort, though discovered over two hundred years ago, is still left at its natural, pristine status, implying that for well over two hundred years, the resources have not been harnessed and no value chain attached.

For much of these years therefore, extraction of raw materials for domestic economy and local industry has been rudimentary and low ebb, while the entire economy maintains a primary value status. Apart from the frog species, seabirds and other water bound animals as well as land animals that are hunted for their game; the resort has a wealth of sedimentary rock deposit, with stratified layers of over twenty-eight feet in some locations.

According to a field report, the sedimentary rock is valued for its quality clay content that can be used in pottery and other ceramic products. In traditional Ibibio society, this quality of clay was and remains significant for many purposes, including its use as a symbolic interactionism medium of communication. In order to explicate further, when achievements such as child birth, victory in local wrestling contests and other sporting events, killing of a notorious wild beast, etc., are recorded by a community member(s), it is often cerebrated. One of the ways to communicate the achievement, the cerebration and attendant joy to others is the rubbing of paste-clay on the face, arms and legs, by family members and acquaintances of the achiever or victor. So for the average Ibibio man or woman, this symbolises achievement and victory, and communicates the attendant joy thereof. As pointed out in Ekong (2001), traditional Ibibio dancers and music performers were often decorated using native chalks. Notably, body decorations are usually marks with native chalks, drawn on the body of dancers and music performers, to serve as costumes and 
artistic designs which constitute the cultural heritage of the society. This quality of clay is also valued for its medicinal properties. It is used singly or in combination with other elements to form poultice and used as plaster for dressing wounds or massaging parts of the body and for soothing inflammations and body pains.

A paste made from this clay also helps in regulating body temperature. This is recommended for lactating mothers to regulate breast milk for feeding their sucklings. The issue in contention evolves about the claim by Ikot Idaha Community that, whereas the entire area hosting the Ibime water resource has been wrongly claimed by Osuk Ediene Community, they (ie Osuk Ediene) have also encroached further into a greater portion of Ikot Idaha lands adjoining the lbime land area.

As posited in Umor (1999), some twenty decades ago, when the demographic statistics and distribution were low, land in the area had to be valued as fertile, liquid or solid mineral bound or other considerations for such land to be attractive, but now, and with the population revolution of the past five decades, all of that have changed. In contemporary times, any piece of land is highly valued, whether fertile or not, and people are poised to adopt all available means, including overt measures to counter every threat of counterclaim (real or perceived) on any portion of land which they had earlier laid claim to, irrespective of the size, location and availability or otherwise of mineral resource. This is in line with the assertion of Khotari cited in Faleti (2006) that the control and use of (natural) resources lies at the heart of the deepening crises in the world today. Indeed, the use of the Ibime resources had restrictions as only the water resource was open to public use at any time, but one must obtain indigenous status in order to participate and benefit from other resources such as the general game expedition.

According to field sources, the disputed portion of land has been in contention over the past ten decades, and several methods of conflict resolution including brokerage, arbitration and quasi- mediation have been used, either singly or in their combination, but at best only marginal successes have been achieved. In other words, the outcomes of peace resulting from those resolutions were not sustainable. The recurrent crises and attendant resumption of hostilities after settlement and seeming peaceful co-existence, has become very worrisome, and calls for an articulated effort to address the situation. This scenario of crisis recurrence often manifest at the time when the entire area wherein the disputed land situate is tenured for cultivation. Primary sources confirmed that the land tenure system which before the 1900s was a ten yearly regime, and later seven yearly is now put at four- yearly tenure. This is as a result of population pressure on land for food production, settlement and other domestic and/or business purposes in the area.

\section{The Mediating Process regarding the Disputed Land}

In the case of Ibime, with Ikot Idaha and Osuk Ediene communities representing the disputing parties, a panel of mediators constituting of men and 
women of integrity was set up by the Ikono Local Government Council. The panellist include the Paramount ruler of the Local Government Area, One representative of the Local Government Council as Secretary, Clan Head of Ediene and Ikono clans, Village Heads and Secretaries of the disputing communities, Two (2) women leaders from each contending community and Two (2) other representatives each from both communities. These men and women made up the sixteen member panel.

These people among others were expected to be honest, impartial, unbiased and have previous knowledge of the case as well as insight into land boundary matters in general. This action is not new in the history of conflict settlement through reconciliation and resolution for peaceful co-existence in Ibibio land. It could be recalled that in the early 1930s, when a serious dispute arose between Ibiono 1 and 11, over the origin of Ibiono clan and organisation of Native Courts in the clan by the colonial regime, it was the Ibibio Union who wadded into the matter by appointing representatives across the entire Ibibio grand clans (now Local Government Areas) of Uyo, Ikot Ekpene, Abak, Itu, Eket and Opobo, to resolve the dispute amicably (Ukpong, Akpan and Akang, 2001).

\section{Methods}

The major research design adopted in the study is exploratory, however, the combination of descriptive and historical methods have been used as supplementary designs. The idea and process of selecting panel members was strategic, as members were carefully drawn from the three known categories of mediators - Social Network, Authoritative and Independent. The social network mediators consist of those invited because of their affinal relationship with both disputing communities, the authoritative mediators consist of those who relate with the disputants because of their position of authority, for example the Paramount Ruler and representative of the Local Government Council, and the independent mediators consist of those who relate with both disputants in view of their social status in society, but who do not have vested interest in any of the two communities. Here, the choices were drawn from retired high ranking civil servants and renowned business class.

Data were collected through the use of in-depth interviews and analysed using content analysis method. In-depth discussions, group discussions, town hall meetings, and confidential informants, were all juxtaposed into a general survey design and used for the research. The double sampling and the panel sampling techniques have been used in combination to enable a proper crosscheck of data throughout all stages of the work. Panel members were distributed into three sub-groups to meet and have several in-depth interviews and discussions with different groups from both communities on issues that were carefully designed for discussions. At the end of two months of intensive, painstaking and accelerated discussions, the reports of the various sub-groups were submitted and subsequently collated into one final report. 


\section{Results and Discussion}

In this section, a summary of the field experiences from all subgroups are articulated in order to validate deductions from the data.

In the course of unravelling underlying issues that intermittently trigger dispute between the two communities as regards the Ibime water resort, two contending positions became apparent.

The first was that the piece of land in dispute was earlier claimed by Ikot Idaha Community through boundary struggle before the period of Treaty, with Ikot Idaha Community leading the assault. The Treaty was the period soon after the final Dispersion of the Ibibio from Ibom in present Arochukuwu, Abia State. The period of the great Dispersion is set at about seven hundred years ago (Ukpong et al., 2001). As communities settled in their new found lands during the immediate post - dispersion era, agreements were reached by the Ibibio progenitors that as brothers, they should live peacefully among themselves, to abhor unnecessary in-fightings and inter-community skirmishes, and to protect each other's property for the sake of posterity. However, this was not to be, as several in-fightings and trans-community land crises manifested across the entire Ibibio space as each group and sub-group struggled to acquire lands they can call their own (Ukpong-Umo, 2012).

The Osuk Ediene forebears through negotiation conceded to a compromise during this initial struggle (an arrangement that ceded the portion of land in contention to Ikot Idaha Community) and for about ten decades, the portion of land was appropriated by Ikot Idaha people.

The younger Osuk Ediene generation having become aware (though in parts) of the intricacies surrounding the ceding of the land to Ikot Idaha community, began to agitate for a return of the land to Osuk Ediene Community. Field survey supports that Osuk Ediene Community staged the first reprisal contest to reclaim the land between 1517 and $1450 \mathrm{AD}$, approximately 500 - 600 years ago.

The second contending position was that the original claimant of the portion of land soon after the Treaty was Ikot Idaha Community, but in one of their inter-community wars with Ibiaku Ikot Edet, which is an adjoining community on the North Eastern fringe of Ikot Idaha community, they (Ikot Idaha people) solicited that Osuk Ediene (who were noted for their fame in wars at the time) join force with them in order to earn victory in the war. They offered with oath, to cede the Ibime portion of land to Osuk Ediene as reward if they conquer their opponent. The deal was sealed and Osuk Ediene warriors helped them to defeat their adversary in the war. Consequent to this victory, Osuk Ediene Community annexed the Ibime lands and began to use and appropriate the said portion of land as part of Osuk Ediene lands. The ceded land was shared to the warriors from Osuk Ediene who divided same among their various families. Several decades down the line, the younger generations of Ikot Idaha community having been told the story in parts, began to agitate and demand for the Treaty status of the land. 
The mediation panel having properly utilized available tools to derive data from primary sources analysed same and arrived at a conclusion. The draft was solemnly presented to both parties, first separately through both community representatives, before the final report was presented in a solemn gathering of both communities in the presence of invited dignitaries from all walks of life across the adjoining communities. This eventful and colourful presentation took place in 1984. In rationalizing the positions, the panel concluded that Ikot Idaha community was the aboriginal title holder of the said portion of land during the Dispersal, and that it was ceded to Osuk Ediene Community in fulfilment of agreement of war alliance with the earlier.

The agreement was entered into, by the desperate Ikot Idaha Community in the face of a looming war between her and an adjoining Community, Ibiaku Ikot Edet, over ten decades ago. Osuk Ediene, with their famous warriors, joined forces with Ikot Idaha against Ibiaku Ikot Edet, and the later having succumbed to the highly tactful militant of Ikot Idaha who won in the war, the forebears of Ikot Idaha Community were honest to maintain the sanctity of the Pact.

As it is often the case in all societies where oral tradition became the source and only device for storage and retrieval of information, history becomes distorted as subsequent generations lose details after several decades of the occurrence of events. In this case, subsequent generations became fed with distorted information, and encoded messages differed significantly from the original messages, leaving a blurred decoded representation for contemporary generations. This of course leaves a false impression of history. The reports collated from the various sub-groups at the interview stage show wide spread agitations by both parties over a seeming departure from ancient landmarks. There was a common clamour for a re-demarcation of the contended piece of land, and return to the ancient landmarks. 
Table 1: Ethnographic summaries/reports of some major events by subgroups

\begin{tabular}{|c|c|c|c|c|c|}
\hline \multicolumn{2}{|c|}{ Group A } & \multicolumn{2}{|c|}{ Group B } & \multicolumn{2}{|c|}{ Group C } \\
\hline $\begin{array}{l}\text { Responses } \\
\text { from Ikot } \\
\text { Idaha on } \\
\text { persistence } \\
\text { of conflict: } \\
\text { conflict has } \\
\text { persisted for } \\
\text { about } 200 \\
\text { years } \\
\end{array}$ & $\begin{array}{l}\text { Responses } \\
\text { from Osuk } \\
\text { Ediene on } \\
\text { persistence of } \\
\text { conflict: } \\
\text { conflict has } \\
\text { persisted for } \\
\text { well over } 100 \\
\text { years } \\
\end{array}$ & $\begin{array}{l}\text { Responses } \\
\text { from Ikot } \\
\text { Idaha on } \\
\text { persistence of } \\
\text { conflict: } \\
\text { conflict has } \\
\text { persisted for } \\
\text { about } 150 \\
\text { years }\end{array}$ & $\begin{array}{l}\text { Responses } \\
\text { from Osuk } \\
\text { Ediene on } \\
\text { persistence of } \\
\text { conflict: } \\
\text { conflict has } \\
\text { persisted for } \\
\text { about } 200 \\
\text { years }\end{array}$ & $\begin{array}{l}\text { Responses } \\
\text { from Ikot } \\
\text { Idaha on } \\
\text { persistence } \\
\text { of conflict: } \\
\text { conflict has } \\
\text { persisted for } \\
\text { over } 200 \\
\text { years }\end{array}$ & $\begin{array}{l}\text { Responses from } \\
\text { Osuk Ediene on } \\
\text { persistence of } \\
\text { conflict: } \\
\text { conflict has } \\
\text { persisted for } \\
\text { over } 150 \text { years }\end{array}$ \\
\hline $\begin{array}{l}\text { Responses } \\
\text { from Ikot } \\
\text { Idaha on } \\
\text { cause of } \\
\text { conflict: } \\
\text { encroachmen } \\
\text { t into Ibime } \\
\text { adjoining } \\
\text { land by Osuk } \\
\text { Ediene } \\
\text { People }\end{array}$ & $\begin{array}{l}\text { Responses } \\
\text { from Osuk } \\
\text { Ediene on } \\
\text { cause of } \\
\text { conflict: } \\
\text { breach of } \\
\text { boundary } \\
\text { agreement by } \\
\text { Ikot Idaha } \\
\text { people }\end{array}$ & $\begin{array}{l}\text { Responses } \\
\text { from Ikot } \\
\text { Idaha on cause } \\
\text { of conflict: } \\
\text { Ibime land } \\
\text { reclaimation } \\
\text { attempt by } \\
\text { Osuk Ediene } \\
\text { long after } \\
\text { Treaty }\end{array}$ & $\begin{array}{l}\text { Responses } \\
\text { from Osuk } \\
\text { Ediene on } \\
\text { cause of } \\
\text { conflict: } \\
\text { reaction to the } \\
\text { caveat on } \\
\text { Ibime by Ikot } \\
\text { Idaha people }\end{array}$ & $\begin{array}{l}\text { Responses } \\
\text { from Ikot } \\
\text { Idaha on } \\
\text { cause of } \\
\text { conflict: } \\
\text { illegal } \\
\text { usurpation of } \\
\text { Ibime by } \\
\text { Osuk Ediene } \\
\text { People }\end{array}$ & $\begin{array}{l}\text { Responses from } \\
\text { Osuk Ediene on } \\
\text { cause of } \\
\text { conflict: } \\
\text { reaction to } \\
\text { attempt to } \\
\text { reclaim Ibime } \\
\text { by Ikot Idaha } \\
\text { people }\end{array}$ \\
\hline $\begin{array}{l}\text { Responses } \\
\text { from Ikot } \\
\text { Idaha on } \\
\text { issue of pact } \\
\text { to cede the } \\
\text { portion of } \\
\text { land to Osuk } \\
\text { Ediene: pact } \\
\text { only covers } \\
\text { the ceding of } \\
\text { a small part } \\
\text { of Ibime }\end{array}$ & $\begin{array}{l}\text { Responses } \\
\text { from Osuk } \\
\text { Ediene on } \\
\text { issue of pact } \\
\text { to cede the } \\
\text { portion of land } \\
\text { by Ikot Idaha } \\
\text { to Osuk } \\
\text { Ediene: pact } \\
\text { certified and } \\
\text { covers the } \\
\text { ceding of the } \\
\text { entire Ibime }\end{array}$ & $\begin{array}{l}\text { Responses } \\
\text { from Ikot } \\
\text { Idaha on issue } \\
\text { of pact to cede } \\
\text { the portion of } \\
\text { land to Osuk } \\
\text { Ediene: pact } \\
\text { not certain, } \\
\text { but boundary } \\
\text { demarcation } \\
\text { was effected } \\
\text { to share Ibime } \\
\text { water } \\
\text { resources } \\
\text { about } 6 \\
\text { decades ago }\end{array}$ & $\begin{array}{l}\text { Responses } \\
\text { from Osuk } \\
\text { Ediene on } \\
\text { issue of pact } \\
\text { to cede the } \\
\text { portion of land } \\
\text { by Ikot Idaha } \\
\text { to Osuk } \\
\text { Ediene: pact } \\
\text { certified and } \\
\text { covers the } \\
\text { ceding of the } \\
\text { entire Ibime } \\
\text { over } 10 \\
\text { decades ago }\end{array}$ & $\begin{array}{l}\text { Responses } \\
\text { from Ikot } \\
\text { Idaha on } \\
\text { issue of pact } \\
\text { to cede the } \\
\text { portion of } \\
\text { land to Osuk } \\
\text { Ediene: pact } \\
\text { only covers } \\
\text { the ceding of } \\
\text { only a small } \\
\text { part of Ibime }\end{array}$ & $\begin{array}{l}\text { Responses from } \\
\text { Osuk Ediene on } \\
\text { issue of pact to } \\
\text { cede the portion } \\
\text { of land by Ikot } \\
\text { Idaha to Osuk } \\
\text { Ediene: pact } \\
\text { certified and } \\
\text { covers the } \\
\text { ceding of the } \\
\text { entire Ibime }\end{array}$ \\
\hline
\end{tabular}

* In the Table above, slight variations were observed from the responses of the three sampling groups

\section{Values and Interest Uniting the People}

There are several values uniting the people that constitute the instigating factor behind the peoples' desire for peace. As adjoining communities, both have several common cultural, moral, religious, economic and political values. For instance, in the area of economy, they share common commercial activities as well as common market with membership of producers and consumers associations of particular goods and services drawn from both communities.

On religious values, members of both communities also belong to common religious organisations and church groups/associations. While there is no intention to treat economic and religious values separately as though they are not cultural, marriage is taken here specifically under cultural values. There is 
increased intensity of inter-marriages between people of both communities. Therefore there is a high level of affinal as well as consanguineal relationship between and among both communities.

\section{Conclusion}

The study focused on the use of Mediation as a tool of Alternative Dispute Resolution (ADR) in resolving inter-community boundary land conflict between Ikot Idaha and Osuk Ediene communities in Ikono Local Government Area of Akwa Ibom State. The result of the analyses proved the efficacy of the method in the resolution and management of communal land conflicts.

The Outcome Mapping (OM) schedule was suggested and this involves a consideration and comparison of several peace Pacts made by both communities in the past in an overall attempt to stifle re-emergence of disputes. $\mathrm{OM}$ is a methodology for planning, monitoring and evaluating development initiatives in order to bring about sustainable social change. As the name implies, its niche understands outcomes (the missing middle) of results that emerge downstream from the initiatives' activities, but upstream from longterm economic, environmental, political or demographic changes. OM revealed that, most resolutions were arrived based on compromise, and there were no proper communiqué, position statement or any other formal statement to communicate resolutions to posterity. The means by which resolutions were preserved include oral tradition, mementoes and life plant e.g. Akono (i.e a boundary land life plant).

\section{Recommendations}

The following recommendations are hereby made for an enduring and sustainable peaceful co-existence among both communities:

1. Documentation and preservation through proper storage of the report for posterity and future use, e.g computer storage and hard copy print out.

2. Regular orientation for both communities to be held penultimate to the year which the land has been tenured for cultivation. This is intended to remind people of both communities of the Treaty that was made by their forbears and sealed by oath between the two communities many decades ago - the treaty which the emerging generations must respect and oblige, so as to avert casualties and blood bath.

3. The Treaty is suggested to be celebrated in a solemn convocation involving both communities on a day of the week that corresponds with the long- day of victory of the battle, from the evening of 'Edet' through the morning of 'Editaha'. This solemnization is expected to guide the conscience of members of both communities and help them reflect on, respect and oblige to the position of their forebears regarding the portion of land.

4. Developing and using the water trough as an ecosystem preservation centre, since the area is already a natural habitat for a variety of fauna/ flora species. 
5. Constitution of Ibime land property committee with membership drawn from both communities to manage and implement policies affecting the portion of land for the benefit of both communities.

6. Use of the portion of land for real venture investment that can generate income and accrue profits for both communities and create employment especially for the youths.

7. The Outcome Mapping (OM) was also to be sustained.

\section{References}

Ekong, E.E. (2010) An Introduction to Rural Sociology. Uyo: Dove Publishers.

Ekong, G. (2001) Music in Nigerian culture. In Ukut \& Ogunbodede (Eds.). Nigerian Culture in Perspectives. Uyo: Footsteps Publication.

Egwu, S.G. (2006) Beyond "Rivival of old hatreds": The State and conflict in Africa. In Gaya, B. (Ed.). Introduction to Peace and Conflict Studies in West Africa.

Faleti, A.S. (2006) Theories of social conflict. In Gaya, B. (Ed.). Introduction to Peace and Conflict Studies in West Africa

Gaya, B. (2006) The Methods of Conflict Resolution and Transformation. In Gaya, B. (Ed.). Introduction to Peace and Conflict Studies in West Africa.

Godongs, S. (2006) Mediation and the Mediation process. In Gaya, B. (Ed.). Introduction to Peace and Conflict Studies in West Africa.

Green, A.W. (1960) Sociology. An Analysis of Life in Modern Society. New York: McGraw-Hill Books.

Hoffmann, M. (1992) Third Party Mediation and Conflict Resolution in the Post - Cold War World. In Bayils, J. and Rengger, J. (Eds.). Dilemas of World Politics, New York: Oxford University Press.

Mwanasali, M. (2006) Africa conflict prevention strategies. In Gaya, B. (Ed.). Introduction to Peace and Conflict Studies in West Africa.

Nader, L. (1984) The Recurrent Dialectic between Legality and its Alternatives: The limitations of Binary Thinking. University of Pennsylvania law Review, 132(3): 627-628.

Ukpong, D., Akpan, M. and Akang, N. (2001) Ikono the Cradle of Ibibio Nation. 1st ed. Uyo: Dorand Publishers.

Ukpong- Umo, R.E. (2013) Conflict and Social Group - An Introduction. Uyo: MEF and MCBroom Publishers.

Umor, R. (1999) Kinship System and Change in Osuk Ediene. Unpublished Undergraduate Project Work of the Department of Sociology, University of Port Harcourt.

Ukpong- Umo, R.E. (2012) Change and continuity in the social institutions of Osuk Ediene community: A social anthropological study. A Ph.D thesis of the Department of Sociology and Anthropology, University of Uyo, Nigeria. 